3.52 Overall, it appears that the UPEB experience can be represented as an example of the successful implementation of a flexible export tax regime by a group of countries acting in concert. It has enabled the UPEB members' governments to earn considerable revenues without a decline in export volume, their share of world exports rising from 43 per cent in 1974 to 52 per cent in 1981. There may be still more scope for such revenue raising activities, and the estimates of this study indicate that the optimal export tax rate for bananas ranges from 20 to 80 per cent (Table 12) above existing rates. If the banana exporters levied a 20 per cent tax, it is estimated that their annual export eainings would increase by 7 per cent and yield US $\$ 255$ million in tax revenue.

\title{
IV. ASSESSMENT OF COMMODITIES SUITABLE FOR EXPORT TAXES
}

4.1 To the extent that developing countries remain the major suppliers, they have an incentive as well as an opportunity to exercise market leverage and gain economic advantage through cartel action and, in particular, through export taxation. The dependence of the developed market economy countries on the developing countries for supplies of primary products, including minerals, is highlighted by the fact that as a proportion of their apparent consumption, imports of primary products from developing countries were 20 per cent as against 3 per cent in the case of manufactures. Imports of fuel (coal, petroleum and gas) from the developing countries in 1979/80 constituted on average 51 per cent of apparent consumption in the developed countries (ranging from 77 per cent in Japan to 20 per cent in the US); those of other minerals averaged 25 per cent (ranging from 37 per cent in Japan to 14 per cent in the US).

\section{(a) Production and Trade Concentration}

\subsection{Several methods can be used to measure the degree of} market power of sellers. The Lerner index, which is the difference between price and marginal cost, purports to measure the deviations from competitive marginal cost pricing 43 . Long-run net profit is another indicator. Cross-price elasticity of demand, which reflects a firm's capacity to exploit price advantage, is a third. The number of sellers in an industry also seems a relevant indicator, since it is inversely related to the degree of monopoly power. However, all these indicators suffer from severe problems relating to data requirements. The most widely-used measure is the concentration ratio, i.e. the share of an industry's total sales (or output/employment/valueadded/assets) accounted for by the largest firms. The existence of cases in which sales or purchases are controlled nationally and the increasing interest in forming international agreements by co-operation among governments make the distribution of national shares in production and trade quite pertinent to examing the market power. 
4.3 The data set out in Table 6 show developing country shares in world production and exports of 29 selected primary products. (The shares of developing countries in developed countries' markets for selected primary products are given in Annex Table 6.) The share in world exports of the six leading developing country exporters of each commodity is also given as an indicator of the potential control of the market by a small group of suppliers. There are sixteen commodities - cocoa, coffee, tea, bananas, citrus fruits, coconut, palm oil, abaca, sisal, jute, tropical hardwood, rubber, bauxite, cobalt, tin, and manganese ore - in which developing countries supply more than 70 per cent of world exports; four commodities - phosphate rock, copper, tobacco, and rice - in which they account for 50-70 per cent of world exports, and enother four - beef, groundnuts, cotton, and iron ore - in which they supply 40-50 per cent of world exports. Moreover, six countries supply more than 70 per cent of world exports of eleven commodities - cocoa, coconut, groundnut, palm oil, jute, abaca, sisal, rubber, bauxite, cobalt and tin, and over 50 per cent of sixteen commodities (coffee, tea, bananas, copper and phosphate rock, in addition to the eleven stated above).

4.4 In some commodities such as lead, zinc and nickel, successful price-raising action may require collaboration between developing and developed countries though the political and economic objectives of this group of countries may be different. However, successful price-raising actions relating to diamonds and uranium demonstrate that realising economic advantage can outweigh other considerations . The availability of large reserves acts as a deterrent against inordinate price increases. The geographical distribution of reserves and the level of investment costs are briefly examined in the next section.

\section{(b) Reserves}

4.5 The size of recoverable reserves of minerals and the number of years they are likely to last at present extraction rates (their "reserve life") will vary with price assumptions. But data for selected minerals set out in Table 7, show diverse positions. The reserve life of bauxite and copper appears to be less than 40 years. In so far as bauxite is concerned, aluminium can be produced from widely abundant clays, hence its supply can be considered ample. Copper reserves can be extended through the exploitation of lower grade ore, but its supply price will tend to be higher. The reserve life of lead, zinc and tin appears to be critical, though workable deposits can be extended through higher prices.

4.6 The geographical distribution of reserves is such that for several minerals - bauxite, copper, cobalt, tin and phosphate rock developing countries account for more than 60 per cent of the world total; however, developed country reserves appear critical (under 5 per cent of world reserves) only for cobalt and tin, which are important to them for strategic reasons. Tin has several competitors including, in some uses, aluminium (see section (e)), while in the case of cobalt, the price increases recorded in the late 1970 s have generated considerable $R$ \& D into cobalt-free alloys in the US45. 


\section{TABLE 6}

The Share of Developing Countries in World Production and Trade of Major Primary Products

\begin{tabular}{|c|c|c|c|}
\hline Commodity & $\begin{array}{l}\text { Share in world } \\
\text { Production } \\
1980\end{array}$ & $\begin{array}{l}\text { Share in World } \\
\text { Gross Exports } \\
1980 \\
\end{array}$ & $\begin{array}{l}\text { Six largest LDC } \\
\text { Exporters' Share of } \\
\text { World Exports } \\
\text { (Average } 77-79 \text { ) }\end{array}$ \\
\hline Coffee & 99.1 & 94.9 & 51.9 \\
\hline Cocoa & 99.9 & 83.0 & 80.2 \\
\hline Tea & 84.2 & 88.9 & 68.2 \\
\hline Sugar & 57.2 & 45.4 & 19.2 \\
\hline Beef & 35.1 & 47.7 & 13.2 \\
\hline Bananas & 97.0 & $97 \cdot 1$ & $64 \cdot 4$ \\
\hline Citrus Fruits & 58.1 & 73.2 & . \\
\hline Rice & 89.8 & $57 \cdot 5$ & 33.7 \\
\hline Soybean & 37.9 & • & $\ldots$ \\
\hline Coconut & 100.0 & 100.0 & $92.1 / 81.6 \underline{a}$ \\
\hline Groundnut & 76.0 & 45.0 & 92.1 \\
\hline Palm oil & 100.0 & 97.1 & 81.9 \\
\hline Cotton & 59.0 & 42.9 & 25.7 \\
\hline Jute & $97 \cdot 5$ & 100.0 & $93 \cdot 3$ \\
\hline Abaca & $\cdots$ & 96.2 & 9.5 .8 \\
\hline Sisal & $\cdots$ & 98.2 & 96.7 \\
\hline Rubber & 97.4 & 100.0 & 94.8 \\
\hline Tobacco & 61.1 & 57.1 & $28 \cdot 3$ \\
\hline Tropical Hardwood & 100.0 & . & .. \\
\hline Bauxite & $52 \cdot 5$ & $71 \cdot 5$ & 77.8 \\
\hline Cobalt & 77.0 & 87.0 & . \\
\hline Copper & 50.0 & 62.8 & 55.8 \\
\hline Iron Ore & 36.4 & 46.3 & 35.1 \\
\hline Lead & 30.6 & 30.0 & 20.7 \\
\hline Manganese Ore & 69.4 & $74 \cdot 5$ & $45 \cdot 4$ \\
\hline Nickel & 28.6 & $33 \cdot 3$ & $\cdots$ \\
\hline Tin & $86: 0$ & $85 \cdot 5$ & 81.2 \\
\hline Zinc & $27 \cdot 4$ & 23.7 & $35 \cdot 1$ \\
\hline Phosphate Rock & 40.8 & 63.7 & $54 \cdot 1$ \\
\hline
\end{tabular}

Notes: .. not available; a copra 92.1 and coconut oil 81.6 .

Sources: The World Bank, "Price Prospects for Major Primary Commodities", July 1982; The World Bank "Commoditiy Trade and Price Trends", August 1981; Metal Bulletin PLC, Metal Bulletin Handbook, 1981 . 
TABLE 7

World Reserves of Selected Minerals by Major Groups of Countries

\begin{tabular}{|c|c|c|c|c|c|}
\hline & $\begin{array}{c}\text { Bauxite } \\
\text { (1) }\end{array}$ & $\begin{array}{c}\text { Copper } \\
\text { (2) }\end{array}$ & $\begin{array}{r}\text { Lead } \\
(3)\end{array}$ & $\begin{array}{c}\text { Nickel } \\
(4)\end{array}$ & $\begin{array}{r}\text { Zinc } \\
(5)\end{array}$ \\
\hline Developed Countries & 24 & 27 & 52 & 23 & 51 \\
\hline Developing Countries & 71 & 61 & 29 & 56 & 40 \\
\hline Centrally Planned Countries & 5 & 12 & 19 & 21 & 9 \\
\hline \multirow[t]{2}{*}{ Reserve Life (years) } & $30-40$ & $35-40$ & $15-20$ & $50-60$ & $15-20$ \\
\hline & $\begin{array}{l}\text { Cobalt } \\
(6)\end{array}$ & $\begin{array}{c}\text { Iron Ore } \\
\text { (7) }\end{array}$ & $\begin{array}{l}\text { Manganese } \\
\text { (8) }\end{array}$ & $\begin{array}{c}\text { Phosphate } \\
\text { Rock } \\
\text { (9) }\end{array}$ & $\begin{array}{l}\text { Tin } \\
(10)\end{array}$ \\
\hline Developed Countries & 4 & 35 & 47 & 8 al & 4 \\
\hline Developing Countries & 79 & 30 & 31 & $67 \underline{\mathrm{b}} /$ & 80 \\
\hline Centrally Planned Countries & 17 & 35 & 22 & $5^{\mathrm{c} /}$ & 16 \\
\hline Reserve Life (years) & $50-60$ & $90-100$ & $40-50$ & Over 100 & $15-20$ \\
\hline
\end{tabular}

a/ In the US only

b/ In Morocco only

c/ In the USSR only

Sources: Data for minerals (1) to (5) and (9) are from World Bank "Price Prospects for Major Primary Commodities", Vols. II and IV, July 1982; Cobalt from Congressional Budget office, "Cobalt: Policy Options for a Strategic Mineral", Washington, D.C., September 1982; others from Rex Bosson and Bension Varon, The Mining Industry and the Developins Countries, New York: Oxford University Press, 1977, Tables G.1 and G. 2. 
4.7 Several minerals, including copper, lead, zinc, silver, cobalt, tin, and bauxite, are known to exist under the sea but up-todate estimates of the quantities and values involved are not available. The value of offshore production of oil and gas was estimated in 1976 at around US $\$ 40,000$ million per year 46 . Costs and physical difficulties are significant deterrents even to identifying and measuring ocean-bed mineral deposits, let alone mining them, and such activities to date have been restricted to areas of limited depth near land.

4.8 An important source of sea-bed minerals is nodules ranging in size from a pea to a football. These contain such minerals as cobalt, copper, manganese, and nickel, and are found scattered over the ocean floor. It has been reported that several major companies in the United States, Western Europe and Japan are in the process of perfecting the technology to mine nodules; but major legal and political problems in exploiting them remain, particularly in view of the current US attitude towards the deep sea-bed mining provisions of the Convention on the Law of the Sea.

4.9 Data on investment cost requirements for exploiting seabased resources are not readily available but information relating to land-based minerals is given in Table 8 . This shows investment costs per ton (metal content) of creating additional capacity for selected minerals in both developing and industrial countries, in 1981 US dollars. According to the source of information used, the term 'investment cost' includes the direct costs of exploration, mine construction and provision of infrastructure 47. For copper, manganese and tin these costs are lower in developing countries but it is generally considered that the need to construct infrastructural facilities tends to inflate costs more in developing countries than in developed ones. However, supply lead times in most minerals range between 10 and 15 years, and hence there is no immediate threat to any price-raising arrangements by producers in developing countries.

\section{(c) Production Costs}

4.10 The issue of production costs is relevant to the extent to which there are low marginal cost (short-run and long-run) alternative suppliers outside the group of producers taking concerted action; individual producers can more easily bear the cost of export taxation without loss of market share if their costs are well below the 'world' price.

4.11 A comparison of production costs in the major countries producing bauxite, copper, iron ore, lead, nickel, tin, zinc, phosphate rock, bananas, cocoa, coffee, tea, sugar, and rubber is given in Table 9. It should, however, be emphasized that such comparisons present several difficulties: aggregates hide inter-firm variations within countries and differences in production methods; there is a lack of homogeneity in the output of some commodities (e.g. arabica and robusta varieties of coffee); and there is unavoidable diversity in the assumptions and methods used in the estimation of costs. Nevertheless, the data do illustrate considerable variations, from which it can be concluded that costs are significantly lower in the developing than the developed countries in the case of bauxite, iron ore, and sugar, and are lower in some developing countries for many of the other commodities reviewed. 
TABLE 8

Est imateded Investment Cost per Ton

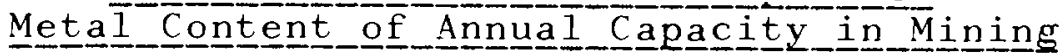

\begin{tabular}{|c|c|c|c|}
\hline Mineral & $\bar{A} \bar{t} \bar{i} \bar{i} \bar{y}$ & $\begin{array}{l}\text { For Additiona } \\
\text { Developing Countries }\end{array}$ & $\begin{array}{l}1 \text { Capacity } \\
\text { Industria } 1 \text { Countries }\end{array}$ \\
\hline & & - & US $\bar{p}$ per Ton $-\cdots$ \\
\hline Copper & Mining & 6,000 & 7,000 \\
\hline Tin & Mining & 4,500 & 5,000 \\
\hline Nickel & $\begin{array}{l}\text { Mining/ } \\
\text { Processiag }\end{array}$ & 37,000 & 36,000 \\
\hline Lead & Mining & 2,040 & 1,540 \\
\hline Zinc & Mining & 2,040 & 1,540 \\
\hline Bauxite $\underline{a}$ & Mining & 75 & 60 \\
\hline Iron Ore $\underline{a}$ & Mining & 63 & 53 \\
\hline Manganese Ore & Mining & 158 & 160 \\
\hline
\end{tabular}

a The investment cost figures are estimated for a "Gross" ton on annual capacity rather than for a ton of metal content. Metal content averages about 23 per cent and 55 per cent for bauxite and iron ore respectively.

Source : World Bank, "Price Prospects for Major Primary Commodities", Vol. 1, July $1982, \mathrm{p} .94$. 


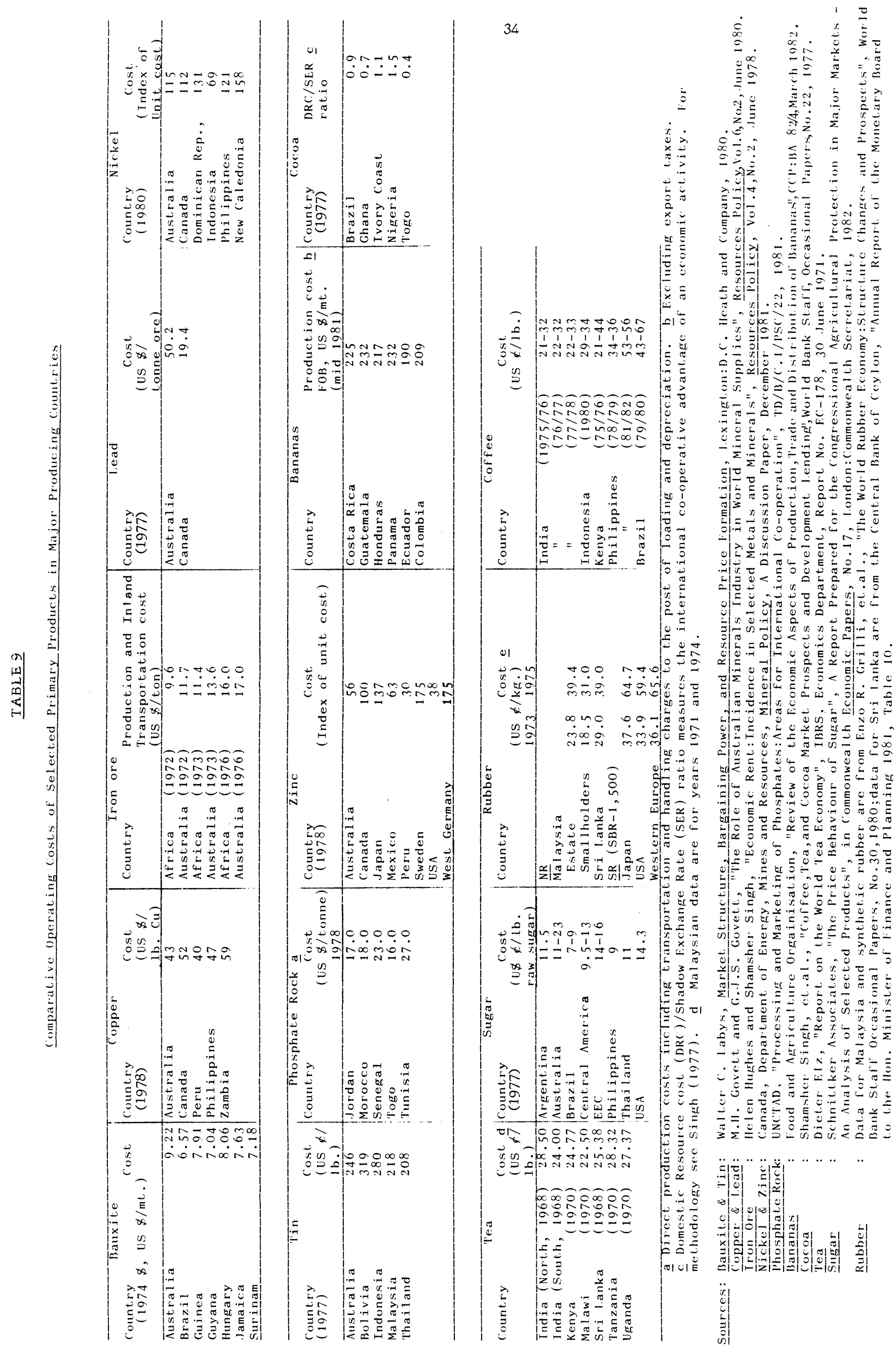


4.12 There are exceptions, however, and for some minerals production costs are relatively lower in Canada and Australia. In the case of copper, they are much lower in Australia than in the developing country producers shown except for Peru, which, because of its competitiveness is keen to expand output.

1.13 Reliable data on lead production costs are available only for Australia and Canada, and they are much lower in the latter. Though several factors determine the level of exports, higher costs partly explain the dramatic decline in Australian lead exports from 72,000 tonnes in 1978 to 22,000 tonnes in 198148 . The wide difference in costs between Australia and Canada indicates the degree of rent accruing to Canadian lead mines.

4.14 Nickel production costs are much lower in Canada and Australia than in some developing countries, but in Indonesia they are even lower as a result of cheaper energy and labour costs. Expensive energy is the main contributor to high costs in New Caledonia, Dominican Republic and Philippines, where conversion from oil to hydro or coal could help make future operations more competitive.

4.15 The operating costs of the three largest South East Asian tin producers - Malaysia, Thailand and Indonesia - are much lower than those of Bolivia, which are even higher than in Australia. Bolivian tin is from underground mines which are much more costly to operate than the alluvial mines of South East Asia; its labour and smelting costs are also much higher. Indonesian costs are above those of its neighbours (including Australia) because of the intensive use of labour and energy to exploit marginal alluvial deposits by gravel pump methods 49 .

4.16 Zinc production costs are lower in Peru, the United States, Australia and Mexico than in other countries, mainly as a result of the occurrence of the metal with others from which it is recovered as a co-product (in Peru, for example, zinc is obtained from copper mines).

4.17 Production costs for phosphate rock differ widely. Among the major developing country producers, Tunisia has the highest costs, and Morocco and Togo the lowest. High costs arise principally from the poor grade of deposits which require additional equipment for mining and benefication. Costs are lower in the United States than in some developing countries but its exports are considered to be of inferior quality 50 .

4.18 Though Ecuador is the lowest cost producer of bananas, its share in world exports has fallen while that of the Central American countries, who forged a marketing arrangement with an export tax, has increased (see section (g), Chapter III for details).

4.19 Cost data on coffee production show considerable differences within and between countries. India is the lowest cost producer, and Brazil the highest. Differences in labour costs are one of the main reasons for the wide divergencies, which are accentuated by the variability of labour utilization rates between varieties of coffee grown. Labour inputes are lower for robusta than for arabica 
coffee because the pruning and spraying required are less 51 . The high production costs in Brazil, which produces mainly arabicas, can be attributed to this factor.

4.20 Tea production costs also differ considerably. They are lowest in Malawi and highest in North India and Tanzania. Higher labour re quirements have reduced the competitive position of India and Sri Lanka, where 3.0 to 3.7 labourers are used on average per hectare, compared with 1.9 to 2.0 in East Africa 52 . The physical output per worker also appears to be lower in India and Sri Lanka, a plucking average of 15 kilograms per worker/day compared with one of about 25 kilograms in Kenya53. The cost estimates in the table do not include export taxes and duties. When the se are included, teas from India (which has recently abolished its export taxes) and Sri Lanka are less competitive and their share in the world market has fallen (see Annex Table 3). Cost differences could be the dominant factor that is preventing consensus on export quotas under the proposed international tea agreement.

4.21 Data on rubber production in Malaysia and Sri Lanka show that smallholders' costs are lowest. Also noteworthy is the competitive position of producers of natural rubber compared to those of synthetic rubber (see discussion in section (e)).

(d) Demand for Primary Products

4.22 If demand for primary products is growing, it is possible to envisage supply controls operating with still rising cutput, which calls for somewhat less discipline and creates fewer adjustment problems in exporting countries.

4.23 An important consideration in evaluating price-raising action by producers is thus the buoyancy of demand for their commodities. One international agency has projected the annual growth in world consumption of coffee, cocoa, tea, cotton, rice, coconut, rubber, and tobacco for the period 1980-1995 at a rate which is marginally greater than that for 1961-198063. Comparable data on world imports show a higher import demand projected for these commodities and for sugar, tin and lead. However, in the case of tin, the annual growth rates of both world consumption and imports are projected to be less than one per cent; those for jute are even lower. For cocoa, tea, sugar, citrus fruits, rubber, tobacco, copper, nickel, bauxite (aluminium), iron ore, manganese ore, lead and zinc, world consumption is expected to rise by more than two per cent per year. However, all these rates are much lower than the 5.9 per cent registered for liquid fuels during $1961-80$, one of the factors that favoured the OPEC price-raising action.

4.24 Supply is also of importance. World output of coffee, bauxite, lead, manganese, nickel, phosphate, tea and tin is projected to rise at a lower rate than consumption for the period 1980-1995, whereas the opposite is the case for cocoa, copper, sugar and zinc. In some other primary products - iron ore, rice and rubber, output and consumption are projected to grow at the same rate. In this context, of the eight commodities selected as potentially suitable for export taxes, supply adjustment would need to be greatest for cocoa and copper. 
(e) Substitution and Economies in Use

4.25 A full exploration of the potential for substitution and economies in use would require examination of the end-uses, costs, technology, and relative quantities in which primary products are currently consumed. Substitution is a strong possibility in several product groups - beverages, edible oils, timber, fibres and some minerals. Functional substitution is another possibility 54 . In so far as the proposed export taxation policy is concerned, product substitution problems can be minimized by adopting an integratec approach, e.g. concerted action by all producers of edible oils (coconut, palm oil, groundnut, etc.). However, the substitution issue remains important and is briefly explored below for several commodities - copper, tin, jute, and rubber.

4.26 Over 50 per cent of copper consumption is in the electrical and electronics industry, while other important end-uses are in building construction, transportation and industrial equipment. Demand is affected by several factors, including subsitution (e.g. by aluminium and plastics) and innovations leading to economies in usage. In the communications industry, several innovations, including thinner gauge copper cables, electronic exchanges which miniaturize circuits and equipment, use of optical fibre (glass) cables, and microwave communication that do away with cables, have resulted in such savings. However, development of new markets, including use of solar energy for heating and air conditioning, expansion in the use of electrical vehicles in the transport sector, and increasing use of desalination technology, could mitigate these effects. Although statistical data on these effects are not readily available, the main determinant of copper consumption will continue to be the GDP growth of the industrial countries.

4.27 Tinplate, which accounts for about two-fifths of world tin consumption, faces competition from several materials including aluminium, electrolytic chrome-coated steel (or TFS), plastics and glass. Many mills are equipped to produce both tinplate and TFS, according to the cost differential between tin and chrome. In addition, technological progress has not only enabled the production of thinner steel sheets which require thinner tinplating, but has also (through an electrolytic process) reduced the amount of tin required per unit of tinplate. It has been estimated that growth in demand for tin has been reduced by about one per cent a year through such substitution 55 .

4.28 Nevertheless, tin is the only metal whose price in real terms has increased more or less continuously for the last three decades. Its producers have been able to capture the resource rent element in the price as a result of the international tin agreement and taxation policies of the major producing countries.

4.29 The major synthetic substitute for jute (as well as other hard fibres) is polypropylene, which is derived from crude oil refining. But because increases in the price of crude oil affect the price of prolypropylene only marginally 56, it has been supplied for extended periods at relatively low prices. The problems for producers have been compounded by that fact that the market for jute bags (which accounts for about half the total) has declined whe re bulk handling of agricultural and industrial products - e.g. grains, cement, and fertilizers - have become predominant. 
4.30 The choice between natural rubber (NR) and synthetic rubber (SR) depends on several considerations including technical (end-use requirements), economic (relative prices) and marketing (degree of industry integration) 57 . During 1950 to 1970 , world consumption of rubber increased on average at 6 per cent per annum, while production of NR increased at only 3 per cent. The widening gap was met by SR whose basic feedstock is a by-product of the petro-chemical industry. Synthetic rubber monomers accounted on average for 45 per cent of the total production cost of SR58, while other energy-based inputs (electricity, steam and chemicals) accounted for 20 to 25 per cent. An increase in the price of energy, therefore, will certainly contribute to a higher supply price of SR (Table 10). Comparative cost data on NR and SR given in Table 9 show that the competitiveness of NR has improved since the 1973-74 oil price increase.

4.31 The prices of NR and the two largest forms of SR are set out in Table 10. This shows that since 1978, SR prices have been generally higher than NR, which suggests scope for price-raising action by NR producers.

\section{(f) Foreign Exchange Reserves}

4.32 It has been argued that exporting countries are better able to participate in price-raising action when they have substantial foreign exchange reserves or when the commodity in question accounts for only a small part of the country's total export earnings. However, the examples of OPEC and the International Bauxite Association (IBA) do not support this view. The reserve position of some OPEC members before the oil price hike in 1973-74 was not very different from that of a typical primary exporting country 59 . Moreover, most were more dependent on oil earnings than were IBA members on bauxite earnings.

\section{(g) Forward Shifting of the Tax Burden}

4.33 The proportion of an export tax that can be shifted to foreigners, on the basis of foreign and domestic supply elasticities, was shown in Chapter III. An index which takes into account not only price elasticities but also other factors (production and export concentration, presence of vertically integrated multinationals, product homogeneity, financial strength of producers, inventory situation, the existence of a scrap market in the case of minerals, and relative dispersion of major buyers) is presented for 23 primary products in Annex Table 7.

4.34 This index provides a feasibility score which purposts to show the likelihood of an export tax being passed on, in full or in part, to foreign consumers and thus its success in raising export revenue. Petroleum (72), bauxite(70), cocoa (70), and bananas (69), products which have been subject to price-raising action by producers, registered high values. However, rice (53), phosphate rock (53) and uranium (45), which were also subject to price-raising action by producers in the mid-1970s, registered much lower values, below those of tea (64), rubber (64), edible oils (62), sisal (58), coffee (57), jute (56), copper (56), and tin (55); cotton (52) and tropical timber (47), also registered scores higher than that of uranium. 
TABLE 10

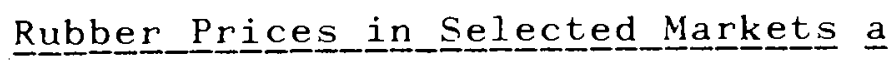

$(\mathrm{US}, \$ / \mathrm{mt}$.

\begin{tabular}{|c|c|c|c|c|c|c|}
\hline \multirow{2}{*}{ Period } & \multicolumn{2}{|c|}{ NR Prices, RSS 1} & \multicolumn{4}{|c|}{ SR Prices } \\
\hline & New York b & London $\mathrm{c}$ & $\begin{array}{c}\text { SBR } \\
\text { London }\end{array}$ & $\begin{array}{l}1,500 \\
\text { Germany }\end{array}$ & London & Rermany \\
\hline 1971 & 399 & 368 & 425 & 387 & 459 & 458 \\
\hline 1972 & 402 & 373 & 442 & 408 & 478 & 470 \\
\hline 1973 & 785 & 776 & 483 & 479 & 524 & 561 \\
\hline 1974 & 868 & 776 & 812 & 521 & 868 & 579 \\
\hline 1975 & 659 & 671 & 858 & 793 & 919 & 793 \\
\hline 1976 & 872 & 876 & 758 & 794 & 812 & 794 \\
\hline 1977 & 917 & 905 & 866 & 866 & 975 & 866 \\
\hline 1978 & 1,108 & 1,044 & 1,046 & 971 & 1,257 & 1,001 \\
\hline 1979 & 1,423 & 1,288 & 1,311 & 1,196 & 1,628 & 1,217 \\
\hline 1980 & 1,625 & 1,488 & 1,621 & 1,408 & 1,868 & 1,480 \\
\hline 1981 & 1,252 & 1,140 & 1,519 & 1,283 & 1,747 & 1,416 \\
\hline
\end{tabular}

a The source has indicated London and German prices in national currencies. These were converted to US $\$$ using exchange rates given in IMF, "International Financial Statistics", Various Issues.

b New York quotations refer to sellers' asking prices for delivery the current month.

$\subseteq$ London prices are buyers prices (spot).

Source: The International Rubber Study Group, "Rubber Statistical Bulletin", Vol. 36, No.8/9, May/June 1982 . 
The scores registered by manganese (44), sugar (43), lead (42), zinc (42), nickel (40) and iron ore (39), appear to indicate a relatively low feasibility of shifting the tax burden to foreigners.

\section{(h) Revenue Gains}

4.35 The revenue gains under an agreed system of export taxes levied by exporting developing countries on 17 primary products coffee, cocoa, tea, bananas, sugar, rubber, cotton, tropical timber, palm oil, phosphate rock, bauxite, copper, iron ore, zinc, nickel, manganese ore, and tin - are presented in Table 11. The method employed in estimating the gains was taken from an UNCTAD study on tea (see FAO 1974).

4.36 The UNCTAD model made several assumptions. First, that all developing countries which are significant producers of the primary product concerned would levy a uniform ad valorem tax on exports of the product to all destinations. Second, that the tax would be additional to existing export taxes and would not, the refore, affect the relative competitive position of the countries. Third, that price elasticity is constant at any point on the demand schedule.

4.37 The supply and demand elasticity estimates used in the calculations (see Annex Table 2) show differences for the same product within and between countries. This could be due to several factors, including differences in the type of product used in estimation ( $\mathrm{e} . \mathrm{g}$. most elasticity estimates for coffee are made on the basis of robustas but occasionally use arabicas) and differences in methodologies adopted by different authors.

Westlake (1977) has pointed out that supply elasticities vary between countries due to differences in production functions. This can happen when there are considerable differences in technologies and factor prices, but primary production technologies are not usually dissimilar between developing countries (e.g. tea production in India and Sri Lanka). Smallholders' production functions may not be very different either, since their main input is labour. Though factor prices differ between countries, there is a tendency for these to move towards equality in the long run. In the short ran, a small price increase by members of a producers' association acting in concert may not lead to a considerable increase in output in non-members. Several factors are relevant, including institutional constraints, (e.g. distribution of land, credit facilities, etc.), relative prices (which might favour a movement of resources to non-taxed commodity), high marginal propensities to consume and over-valued exchange rates. Howrever, to take account of the disparities in elasticities, two sets of calculations were performed: scenario I, which used low elasticity values, and scenario II, which used high ones. In addition, both scenarios used separate sets of demand elasticities for developed and developing countries; such a distinction could not, however, be made between demand elasticities in exporting and importing developing countries, due to data limitations. In the case of supply elasticities, the same sets (low and high elasticities) were used for both developed and developing countries, due to paucity of data. 


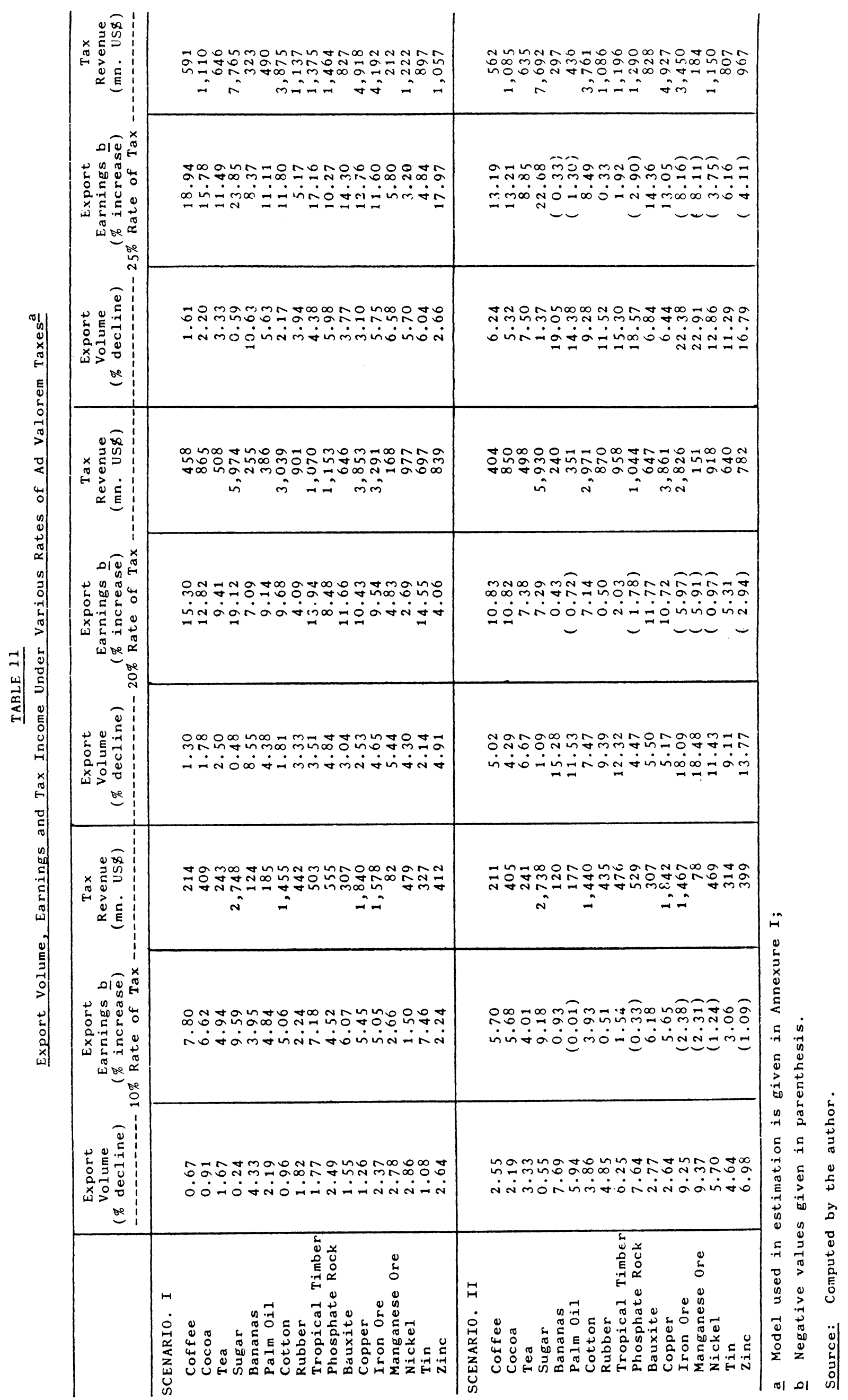


4.38 Three ad valorem tax rates - 10 per cent, 20 per cent, and 25 per cent - were used in the computations. Estimates can be made on the basis of higher rates, but because the elasticities may change at higher absolute prices, since consumers and producers are likely to react differently to very steep changes, no firm conclusions can be drawn from such estimates.

4.39 The estimates illustrate the potential revenue that can accrue to developing countries by levying a uniform ad valorem tax on their exports of the 17 primary products cited. Had the countries employed a 10 per cent tax in 1980 on eight selected products - coffee, cocoa, tea, bananas, bauxite, copper, tin and tropical timber - it is estimated that under the low elasticities of scenario I they would have received as tax revenue an amount equivalent to US $\$ 4.0$ billion; at 20 per cent the amount would have been US $\$ 8.4$ billion, and at 25 per cent, US $\$ 10.7$ billion. These amounts were found to be only marginally less when recalculated using the high elasticities of scenario II, when the corresponding figures would be US $\$ 3.9$ billion, US $\$ 8.1$ billion and US $\$ 10.3$ billion.

4.40 Since it is assumed that the tax is levied on exports to all destinations, part of the potential revenue would have been raised at the expense of the developing countries themselves. But as over 85 per cent (weighted average) of the exports of the eight products selected went to the developed countries, this burden would not have been very great, although it would have varied between products (from near zero for bauxite to about 20 per cent for tea).

4.41 Estimates of export eamings show that under the low elasticity scenario I they increased even at a 25 per cent rate of tax, which suggests that the optimum rate may be even higher.

4.42 However, corresponding estimates under the high elasticity scenario II show that even with a 10 per cent rate, export earnings would decline in six cases - palm oil, phosphate rock, iron ore, zinc, nickel, and manganese ore, although in no case was the decline more than 2 per cent. These products would require careful attention if such tax policies were to be implemented. At a 25 per cent tax rate, increases in export earnings for the remaining products were as follows: sugar ( 23 per cent), bauxite (14 per cent), cocoa (13 per cent), coffee (13 per cent), copper (13 per cent), tea ( 9 per cent), cotton ( 8 per cent), and tin ( 6 per cent). Comparable estimates for these products are marginally higher under the low elasticity scenario I.

4.43 Turning to the effects of export taxes on the quantities exported, it was found that under the low elasticity scenario $I$, the declines caused by a 10 per cent tax rate would be less than 3 per cent in all 17 products except bananas (which would fall 4 per cent); at a 20 per cent tax rate, declines of 3 per cent or more would occur in ten products - bananas ( 9 per cent), manganese ore $(5$ per cent), zinc ( 5 per cent), iron ore ( 5 per cent), phosphate rock ( 5 per cent), nickel ( 4 per cent), palm oil ( 4 per cent), tropical timber ( 4 per cent), rubber ( 3 per cent), and bauxite ( 3 per cent). Even at a 25 per cent rate, quantity declines in five products - coffee, cocoa, sugar, cotton, and tin - were less than 3 per cent. 
4.44 Comparable estimates under the high elasticity scenario II show far steeper quantity declines: at a 10 per cent rate there would be a decline of more than 3 per cent in twelve products, while at a 20 per cent rate, there would be one of more than 4 per cent in sixteen products. At a rate of 25 per cent, quantity declines of more than 5 per cent would occur in all products except sugar.

4.45 These estimates suggest that the imposition of a uniform export tax, by reducing exports, and therefore output, might induce further price increases, on account of an inventory build. up due to uncertainty over supplies. But the consequences of reduced output on domestic employment could be considerable in labour-intensive activities such as bananas and rubber, especially if altermative employment was not to be found elsewhere in the economy. These effects could, however, be counteracted by increased government expenditure from the export tax revenues, which could be used to facilitate structural adjustment through encouraging investment in altermative activities.

4.46 It has to be recognised, however, that for some products the lower quantities exported as a result of imposing an export tax will cause negotiating problems in certain cases. One way to resolve these problems is to pay compensation to those countries experiencing such reductions in relation to a base year (preagreement). Estimates of such compensation were made for eight products (selected by the previous analysis) on the basis of export supply shifts generated by the model (scenario I in export tax calculations). They show that it would be necessary to keep aside on average 10 per cent of the total export tax revenue generated in the case of coffee and cocoa, 18 per cent for tea, 26 per cent for bananas, 32 per cent for bauxite, copper and tin, and 24 per cent for tropical timber.

4.47 An export tax will have other effects too. After its imposition and to the extent that domestic producers receive a lower price for the taxed product, domestic consumers will gain. Those using the product as an input will experience lower costs of production, encouraging further processing before export, increasing industrial employment and possibly also raising export earnings.

4.48 The UNCTAD method to estimate revenue gains was modified (see Annex II) in order to calculate the optimum export tax rate and the rates which would maximize export revenues and export tax revenues. Fourteen primary products from the UNCTAD model were used, tropical timber, zinc and nickel being excluded due to data limitations. Again, the estimates were based on two sets of elasticities: scenario I using low elasticities and scenario II using high ones. The results are summarised in Table 12. This shows that iron ore, manganese ore and phosphate rock are not suitable for an export tax arrangement (between developing country exporters) of the type considered in this study. Though the results generally agree with the findings of the UNCTAD model, the optimum rates of export tax in the case of sugar, cotton and rubber appear to be considerably lower. 


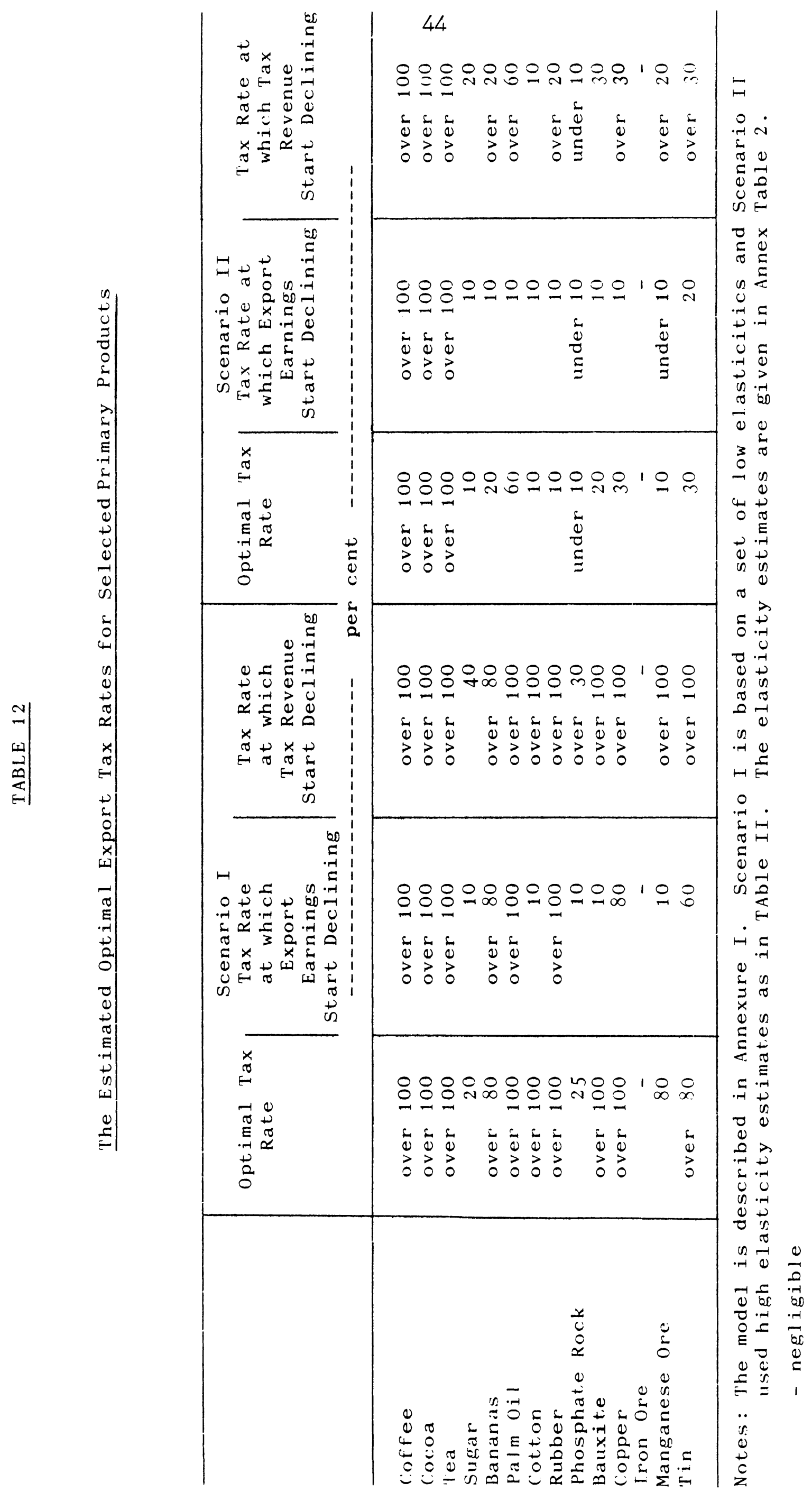

